apparatus. In consequence of this connexion, in fact, the nervous centres connected with the muscles suffer some displacements in relation to the changes of form that the body undergoes when the animal retracts or expands itself; and the nerves themselves, by virtue of the muscular envelope with which they are provided, being able to elongate or shorten themselves, form active bands, which intervene in the modifications which the movements of the animal cause. - Comptes Rendus, September 30, 1872, pp. 769771.

\title{
On Delphinus Desmarestii, Risso (Aliama Desmarestii, Gray).
} By Dr. J. E. Gray, F.R.S.

Risso, in his 'Histoire Naturelle de l'Europe Méridionale,' describes and figures a species of dolphin under the name of Delphinus Desmarestii (vol. iii. p. 24, t. 2. f. 3). As the figures of the two dolphins on the preceding plate are accurate, and his figures in general reliable, and the figure itself agrees with the description, I am inclined to regard it as correct until it is proved otherwise. It has been considered the same as Ziphius cavirostris of Cuvier, a ziphioid whale. It is so unlike all the other ziphioid whales known that it may be considered one of the whales requiring further examination. Instead of having the rounded head and short cylindrical beak and small pectoral and dorsal fin common to all the ziphioid whales, it has an elongated, conical, tapering head, acute in front, with two teeth produced in front of the lower jaw, elongatelanceolate pectoral fins low down on the sides of the body, like the Grampus and Globiocephalus, and a large elongated truncated dorsal fin; and the body is marked with a multitude of irregularly placed white lines, as in Grampus. The female described and figured was nearly 20 feet long.

In the P.Z. S. 1864, p. 242, I proposed a genus for this dolphin under the name of Aliama; but I unwisely placed the Hyperoodon de Corse, Doumet, Bull. Soc. Cuviér. 1842, p. 207, t. 1. f. 2, and Delphinus Philippii, Cocco, Erich. Arch. 1846, p. 204, t. 4. f. 6, which are both true ziphioid whales, probably belonging to the genus Epiodon, as synonyma of the same species. Most probably Doumet's Hyperoodon de Corse is the animal of the skull described as Ziphius cavirostris of Cuvier ; if it is the Ziphius de Corse of Gervais (Ostéog. Cét.), which appears to be a female animal, it is interesting as showing that the inner side of the intermaxillaries of the female animals are dilated and turned up.

This whale has been confounded with Delphinus Desmarestii under the name of Epiodon Desmarestii (see Suppl. Cat. Seals and Whales, p. 98), figured by Gervais, which differs from all other Petrorhynchi in the inner margin of the intermaxillary bones not being nearly so much elevated behind as in that genus, and not elevated but rounded in front, and margining the linear vomer; while in Petrorhynchus the inner edge of the intermaxillaries is dilated, forming a wellmarked concavity round the nostrils, and much elevated on the sides, forming a thin hood over each side of the much-swollen vomer. 
I should propose to call this species Epiodon Heraultii, to distinguish it from Risso's Delphinus Desmarestii. The skull of E. Heraultii and Petrorhynchus cavirostris, as shown in Gervais's figure, is very different; and probably, as the Hyperoodon de Corse of Doumet is proved to be the animal of Petrorhynchus, Delphinus Philippii of Cocco may be the animal of Epiodon Heraultii.

\section{The Swedish Scientific Expedition.}

[Extract from a letter from Mr. J. E. Lindahl to Dr. J. E. Gray.]

My Greenland expedition was very successful. The 'Gladan' shipped the meteorite iron at Disco Island, and then she made a cruise to some places where our geologist, Dr. Nanckhoff, wanted to carry out his explorations ; and Dr. Th. M. Fries, a botanist who had joined the expedition as a private passenger, followed him. I had got the steamer 'Inzegerd' for my dredging-operations. I went up to Upernivik at the 73rd degree of latitude, thence westward till we met the lasting ice; and following the edge of the ice we made southward down to St. John's, Newfoundland, to fall in with the 'Gladan' and return to Sweden in company.

From Cape Terewek to Upernivik, and thence to St. John's, we dropped our dredges at least once for every degree of latitude that we passed, often in pretty good depths of water down to 980 fathoms. In 410 fathoms I got two specimens of the Umbellula groenlandicaI think better Umbellularia encrinus. There is not the slightest doubt that they are not of the same species as those described and figured by Ellis and Mylius. My specimens are younger, only some 12 inches long, and with fewer polypes (about 12), than in the former ones. I am just going to work out a paper upon them, which will probably appear in the beginning of next year. Although these animals are probably the most interesting things brought home by the expedition, they are by no means the only objects of high scientific value. Among the great number of siliceous sponges and starfishes, as well as some other groups of animals, I have reason to believe that many new or rare things are to be found; but nothing is yet examined except the Arachnida, described by Tamerlan Thorell in the ' Efversigt af Kongl. Vetenskaps Akademiens Förhandlingar,' 1872, no. 2, pp. 147-166. I had not much time for explorations on shore. Our physicists, Dr. Nyström and Dr. Fries, assisted in making collections on shore. We found but twenty specimens of Arachnida, nearly all of them new to science. A few of them were also taken by Professor Nordenskiold in 1870 . We collected a pretty good amount of skeletons and implements from some long-abandoned Esquimaux villages. Also temperature soundings were taken; and samples of water from the abysses of Baffin's Bay were brought home. I hope the expedition will prove to have many important results to science; only we want the means of employing scientific people to work it all out; but the Swedes have not copper enough to do such things rapidly.

This summer I have examined the greater depths in Skagerrack 


\section{$2 \mathrm{BHL}$ Biodiversity Heritage Library}

Gray, John Edward. 1872. "On Delphinus Desmarestii, Risso (Aliama Desmarestii, Gray)." The Annals and magazine of natural history; zoology, botany, and geology 10, 468-469. https://doi.org/10.1080/00222937208696747.

View This Item Online: https://www.biodiversitylibrary.org/item/81231

DOI: https://doi.org/10.1080/00222937208696747

Permalink: https://www.biodiversitylibrary.org/partpdf/63362

\section{Holding Institution}

Smithsonian Libraries

\section{Sponsored by}

Smithsonian

\section{Copyright \& Reuse}

Copyright Status: Public domain. The BHL considers that this work is no longer under copyright protection.

This document was created from content at the Biodiversity Heritage Library, the world's largest open access digital library for biodiversity literature and archives. Visit BHL at https://www.biodiversitylibrary.org. 